\title{
エロージョン・コロージョンのテクニカルモデュール
}

\author{
酒井潤一* 伊藤 慶* 木原重光** \\ * 早稲田大学 基幹理工学部 \\ ** 株式会社ベストマテリア
}

\section{Technical Module of Erosion-corrosion}

\author{
Jun’ichi Sakai*, Kei Ito* and Shigemitsu Kihara** \\ * Waseda University \\ * Best Materia Co.,Ltd.
}

\begin{abstract}
RBM (Risk Based Maintenance) is a promising method of maintenance for aged plants. The Risk is defined as the product of likelihood and consequence of failure. The likelihood of failure is evaluated by prediction of residual life or sensitivity of failure and degradation. Technical module is a tool to evaluate the likelihood of failure. In this paper development of technical module for erosion-corrosion which is one of the most likely mechanism of failure in aged plants is introduced.
\end{abstract}

Key words : Risk Based Maintenance (RBM), technical module, erosion-corrosion, residual life, likelihood of failure

\section{1.は じめに}

昨今, 大きな産業事故の発生など, 我が国の産業設備 の安全に関する信頼が摇らいでいる，図 $1^{11)}$ に示す高圧 ガス保安法にかかわる過去 40 年間の年別事故件数推移 は，近年事故件数が増加傾向にあることを示している. すでに成熟社会となりつつある我が国は，膨大な社会・ 産業資産としての構造物を有しており，これらの構造物 を大切に維持, 活用することが重要な時代になっている と考えられる。

最近の事故の原因として, 構造物の老朽化, 保全関係 技術者の減少, 技術伝承の不備, 時代遅れの規制などの 問題が指摘されている。一方で, 国際競争の激化の中で, すべての製造業においてコストダウンは必須である。ま た，社会インフラにおいても老朽化した構造物において 安全を損なうことなく，低コストで維持することが求め られている．産業のみならず社会インフラを含めた構造 物維持のための合理的保全の重要性を認識しなければな らないといえる．産業インフラの主構成材料である金属 材料では, 長い歴史の中で事故の原因となる破損機構は ほとんど解明されてきたが, 残念ながら近年の事故は過 去に経験した事象の繰返しである。過去の研究成果を広 く誰でもが容易に使える手段にしていくことが必要であ る. 2004 年 8 月に作業員 5 人が死亡した美浜原子力発電 所の高温蒸気噴出事故 ${ }^{2)}$ の原因として, 一般にも知られ るようになったエロージョン・コロージョンも古くから 経験している損傷機構であり, 何らかの方法で予知でき なかったかと悔やまれる。

一方，近年の規制緩和によって，各種プラントにおけ る定期検查が法定から自主検査に移行しつつあり, 効率

* \% 169-8555 東京都新宿区大久保 3-4-1 (3-4-1, Ookubo, Shinjukuku, Tokyo, 169-8555 Japan)

** T190-0001 東京都立川市若葉町 2-2-1（2-2-1, Wakaba-cho, Tachikawa-city, Tokyo, 169-0001 Japan)
的な自主基準が必要となってきている．2005 年 4 月から 高圧ガス製造設備の保安検査方法に関する制度が改正さ れ, 従来の省令 (技術基準) による保安検査から, 事業 者が主体的に実施する定期自主検查に重点が移る $\left.{ }^{3)}, 4\right)$. 検査の技術基準は省令から民間規格（例えば 2007 年度 に制定が見达まれる高圧ガス保安協会規格など）による ことになり，時間計画型（Time Based）から状態基準型 (Condition Based) 検査が主体となると考えられる。懸 念される損傷の度合の評価を基準にして, 各部位に対す るメンテナンスの重要度, 緊急度, 優先順位を決めてメ ンテナンスを行う方法が，これらのニーズに合致するも のである.

そのような中で, 欧米から始まったリスク（破損の起 こり易さ×破損による被害の大きさ）を基準にした維持 管理手法である RBI/RBM(リスクベースインスペクショ ン/メンテナンス）が今後のメンテナンス手法の主流とな ると考えられている ${ }^{5)}$. RBI/RBM 手法は, リスクの大き さを指標に保全の優先順位を付けることで, 無䭾な検査 を省略し，リスクの大きいところに優先的に投資がなさ れるという合理的な手法である。 RBI/RBM において最 も重要なことはリスク評価の信頼性であり, すべてのメ

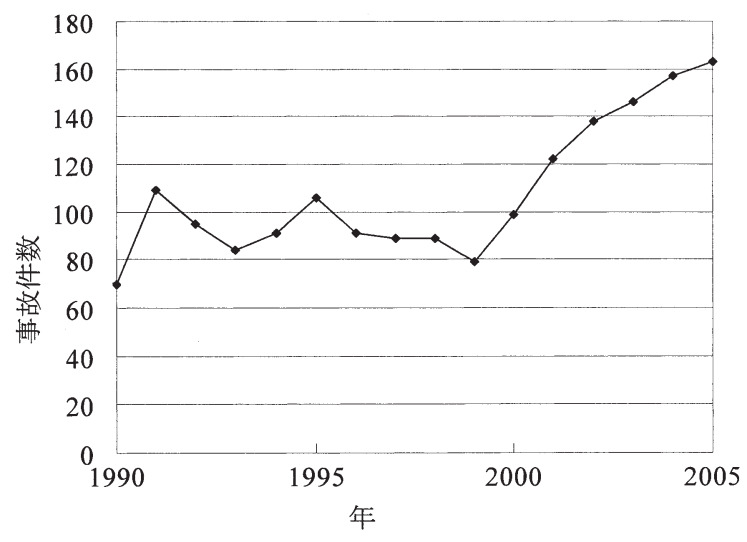

図 1 高圧ガス保安法関係事故件数の推移 
ンテナンス手法と同様に損傷の起こり易さを破損確率, 余寿命あるいは発生感受性などとして算定することであ る.

本報告では，RBI/RBM における破損の起こり易さ算 定のツールであるテクニカルモデュールをエロージョ ン・コロージョンを対象に開発した成果を中心に述べ る。このテクニカルモデュールは，(財)エンジニアリン グ振興協会「産業・社会資本構造物の長寿命化に向けた 高度メンテナンスシステムの開発」プロジェクトの開発 成果6)である。

\section{2. リスクベースインスペクション/ メンテナンス（RBI/RBM）}

\section{$2.1 \mathrm{RBI} / \mathrm{RBM}$ の概要}

RBI/RBM は，リスクを基準にメンテナンス（検査， 補修, 改造, 更新など）を行う手法で, リスクの高いと ころに手厚いメンテナンスを実施して，リスクを低減し， 全体のリスクレベルが許容範囲以下になるようにメンテ ナンスが計画される.

$\mathrm{RBI} / \mathrm{RBM}$ においてリスクは「故障, 破損の起こり易 さ」と「起きた場合の被害の大きさ」の積として表現さ れる. 米国石油学会 $(\mathrm{API})^{7), 8)}$, 米国機械学会 $(\mathrm{ASME})^{9), 10)}$ がRBI についてのガイドラインを示しているが，その中 でリスクの半定量的表現方法として，図 2 に示すような 縦軸に「故障, 損傷の起こり易さ」, 横軸に「起きた場 合の被害の大きさ」をとったマトリックス表示を推奨し ている (縦軸, 横軸の区分け数の決まりはない. 図 2 で は $4 \times 4$ とした)．各部位の懸念される損傷に対するリス クは縦軸「故障, 破損の起こりやすさ」と横軸「起きた 場合の被害の大きさ」を査定して図 2 にプロットされる。 査定の結果，リスクが許容範囲 (リスクレベルごとの対 処方法は経営的判断を含めてあらかじめ設定される) を 越えている機器, 部位に対して, リスクが許容範囲に入 るようにするための検査, 補修, 改造, 更新計画が RBM によるメンテナンス計画となる。結果として，プ ラント全体のリスクが一定值以下となって, 安全で効率 的な運転を可能にすることになる。リスクの低減は縦軸 を下げる（損傷を起きにくくする）か横軸を左に寄せる （被害を小さくする）ことによって達成できるので，マ トリックス表示することでリスク低減策が検討しやすく なる。また，現状で許容範囲にある部位に実施されてい る検査をなくしてもリスクレベルが変わらずに許容範囲 にあるなら，その検査は省略が可能なことを意味する。

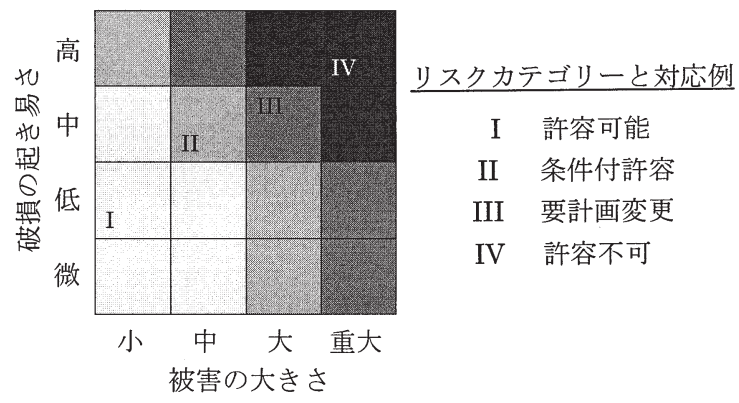

図 2 リスクマトリックと対応例
結果的に検査項目を減らすことを可能にし，RBM はメ ンテナンスコストの削減も可能にするといえる.

\section{2 国内外動向}

規制緩和，自由化が進んでいる欧米では，古くから自 主基準でメンテナンスを行っており，石油メジャーでは， 膨大なプラントを効率的にメンテナンスするために，以 前から RBI/RBM 手法を実践している。米国石油学会 (API) が石油精製プラント向けのリスクベース検査 (RBI) のガイドライン7), 8), 米国機械学会 (ASME) も 各種プラント用の RBI ガイドライン9),10) を作成し, 最近 ではASME/API の統合によるガイドラインの開発が進 められている，米国では，膨大な点検，検査が必要であ る原子力発電所における検査の効率化のために, リスク の考え方を取り入れた検査方法が検討されている．米国 原子力規制委員会 (NRC) がリスクインフォーム規制の 適用を積極的に進めており, 電力業界, 電力研究所 $(\mathrm{EPRI})^{11)}{ }^{12}$, $\mathrm{ASME}^{13)}$ も前向きで，原子力発電所のメン テナンスに対して, RBIの適用は確実に進むものと思わ れる14)

欧州では，RIMAP(Risk Based Inspection and Maintenance Procedure for European Industries) プロジェクト を推進し，欧州全体で同一基準で RBI/RBM を実施する ために必要な手法の開発を行っている，また，欧米では， 多くのコンサルティング会社が，RBI/RBM のソフトウ エア販売やコンサルティングを提供している.

近年, 国内でも学協会が RBI/RBM 手法の確立のため の活動を行っている. 日本高圧力技術協会（HPI）では RBM 研究委員会（委員長：酒井信介東京大学教授）が 日本高圧力技術協会基準 (HPIS) として RBI ガイドライ ン15) および RBI ハンドブック16)を発刊する予定である. (財)エンジニアリング振興協会では, (財) 機械システム 振興協会からの委託研究として,「機械システム等のメ ンテナンス最適化のための RBM 手法の開発に関するフ イージビリティスタディ」17) 2003 年から 2 年間実施し た。また，同協会は 2004 年から国家プロジェクトとし て「産業・社会資本構造物の長寿命化に向けた高度メン テナンスシステムの開発」を 3 年間実施し, RBI/RBM に必要なツールの開発を行った ${ }^{6)}$. (独) 日本学術振興会 は 2004 年度から「化学プラントのリスクベース保全技 術」に関する先導的研究開発委員会が調査活動を行い, 2007 年度から産学協力研究委員会「リスクベース設備管 理第 180 委員会」(委員長：酒井潤一早稲田大学教授) を設置し活動している.

また, 火力発電用ボイラ ${ }^{18)-20)}$, LNG タンク ${ }^{21)}$, クレー ${ }^{22)}$ ，セメントプラント ${ }^{23)}$, 蒸気タービン ${ }^{24)}$, への RBM の適用が報告されている， RBM 実施に参考になる書 籍25),26) も出版されている.

\section{3 リスク評価}

当然のことながら，RBI/RBM で重要なことはリスク の算定である。リスクは「破損の起こり易さ」と「破損 が生じた結果として生ずる被害の大きさ」の積である. 従って, リスクは,「破損の起こり易さ」と「破損が生 じた結果として生ずる被害の大きさ」, それぞれの算定 によって求められる。ここでは「破損の起こり易さ」の 
算定方法について述べる。

一般的に「破損の起こり易さ」は，破損確率，余寿 命㧍よび発生感受性として表現できる。リスクの評価 には定性的，半定量的扔よび定量的評価がある。定量 的評価は，破損確率と被害の金額の積として表現され るが, 破損確率のデー夕がそしく信頼性に問題があり， 評価コス卜も掛かるため, 定性的, 半定量的評価の後 に，大きな投資となる設備の評価などに限定して適用 される。一方，余寿命抢よび発生感受性は，多くの損 傷機構研究の成果を利用することで，比較的容易に評 価できる. 余寿命および発生感受性評価結果を, 図 2 の縦軸のようにレベル分けして「破損の起こり易さ」 の評価とする方法が, 半定量的評価方法として広く使 われている。

\section{3. テクニカルモデュール}

具体的に「破損の起こり易さ」の評価を行うには, 対象となる機器 (部位) において懸念される損傷機構 を特定して，その損傷機構に対する損傷確率，余寿命 または発生感受性評価を行うことになる。損傷機構を 特定するためのツールとして, 損傷劣化機構スクリー ニングプログラム ${ }^{6}$ が利用できる.

余寿命および発生感受性評価のためのツールとし て, API PUBLICATION 581 (Risk-Based Inspection Base Resource Document) ${ }^{8)}$ では, テクニカルモデュ ールを用意している。テクニカルモデュールとは，使 用材料，環境などの条件についての質問に順次答える と，その損傷機構に対する余寿命または発生感受性が 求められる手順を示したものである.

例として, 四 3 にAPI581に扮ける 18Cr-8 $\mathrm{Ni}$ 系ステ ンレス鋼の塩化物応力腐食割れの感受性を評価するテ クニカルモデュールのフロー図を示す. 塩化物イオン 濃度, 温度, $\mathrm{pH}$ によって割れ感受性の程度を評価で きるものとなっている.

API581 Appendix には, 表 1 に示す損傷機構につい てのテクニカルモデュールが掲載されている.

\section{4. エロージョン・コロージョン事例 から見る影響因子}

テクニカルモデュールの作成には, 損傷メカニズム を理解し, 損傷の程度を決める要因を明確にすること が不可欠である。

一般に，エロージョン・コロージョンは流体の衝突 により金属表面 (皮膜) が除去され，母材の溶解が著 しく加速される現象として理解されている．流体によ る機械的な皮膜除去はないが, 流速により腐食が促進 される現象は流動加速腐食 (FAC) と呼び, エロージ ヨン・コロージョンと区別される場合があるが，ここ では広義の流体中加速腐食をエロージョン・コロージ ヨンとして扱う。エロージョン・コロージョンの機構 を解説した文献27)-29) によれば, 材質 (硬さ), 流速, 流体の状態 (単相, 混相), 乱流度合, 流体の腐食性, 金属温度がエロージョン・コロージョンの損傷程度を 決める主因子と考えられる。

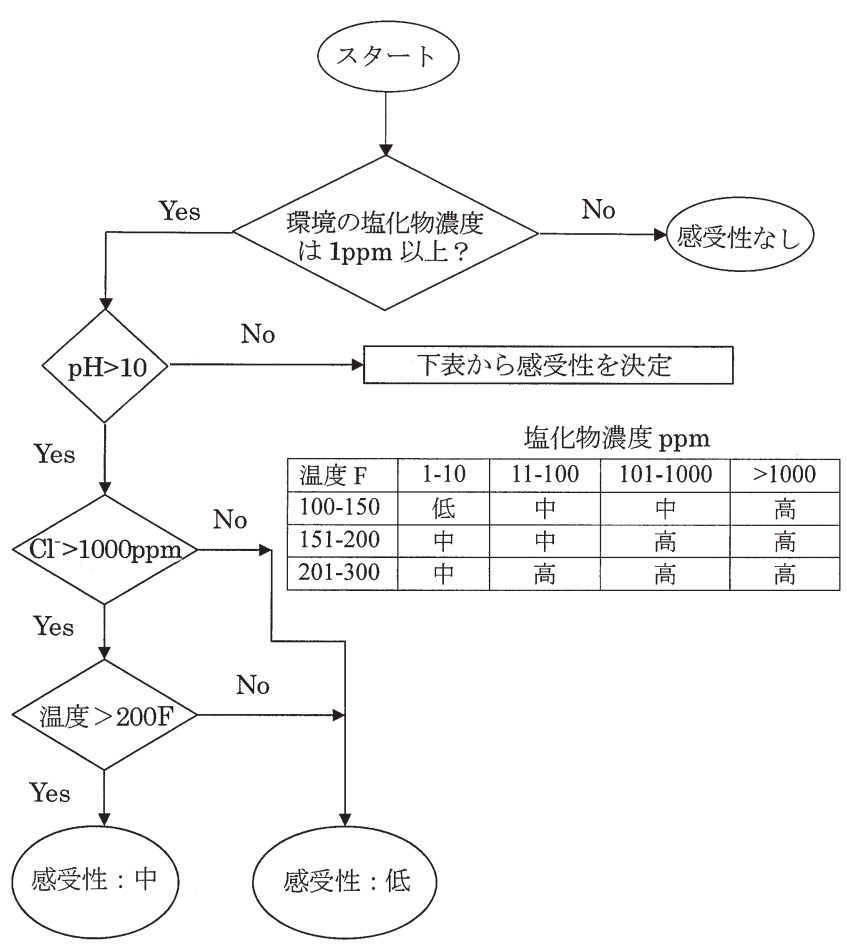

図 3 API581 の塩化物応力腐食割れ感受性を求めるテクニカルモ デュールのフロー

表 1 API581 に示されている損傷機構とテクニカルモデュール

\begin{tabular}{|c|c|}
\hline 損傷機構 & テクニカルモデュール \\
\hline \multirow{8}{*}{ 全面堿肉 } & 塩酸腐食 \\
\hline & ナフテン酸腐食 \\
\hline & 高温水素／硫化水素腐食 \\
\hline & 硫酸腐食 \\
\hline & フッ酸腐食 \\
\hline & サワー水腐食 \\
\hline & アミン腐食 \\
\hline & 高温酸化 \\
\hline \multirow{9}{*}{ 応力腐食割れ } & 苛性割れ \\
\hline & アミン割れ \\
\hline & 硫化物応力割れ \\
\hline & 水素锈起割れ (硫化水素中応力水素誘起割れ) \\
\hline & 炭酸割れ \\
\hline & ポリチオン酸割れ \\
\hline & 塩化物応力腐食割れ \\
\hline & フッ酸中水素誘起割れ (HCS=HF) \\
\hline & $\begin{array}{l}\text { 水素唀起割れ（フッ酸中応力水素誘起割れ） } \\
\text { (SOHIC=HF) }\end{array}$ \\
\hline \multicolumn{2}{|l|}{ 高温水素腐食 } \\
\hline 機械的疲労 & 配管の機械的疲労 \\
\hline クリープ & 加熱炉管 \\
\hline \multirow{4}{*}{ 脆性破壊 } & 低温低鞋性破䁾 \\
\hline & 焼き戻し脆化 \\
\hline & 475 脆化 \\
\hline & $\sigma$ 相脆化 \\
\hline \multirow{4}{*}{ 外面損智 } & 炭素鋼-外面腐食 \\
\hline & 炭素龬および低合金銅の保温材下腐食 \\
\hline & $\begin{array}{l}\text { オーステナイト系ステンレス鋼の外面応力腐食割 } \\
\text { れ }\end{array}$ \\
\hline & $\begin{array}{l}\text { オーステナイト系ステンレス鋼の保温材下外面応 } \\
\text { カ腐食割れ }\end{array}$ \\
\hline
\end{tabular}


表 2 JST 失敗事例検索サイトのエロージョン・コロージョン事故事例と分析

\begin{tabular}{|c|c|c|c|c|c|c|c|}
\hline 損傷機器 - 箇所 & 事故概要 & $\begin{array}{l}\text { 流体 } \\
\text { 状態 }\end{array}$ & $\begin{array}{l}\text { 流速 } \\
(\mathrm{m} / \mathrm{s})\end{array}$ & $\begin{array}{l}\text { 乱流度 } \\
\text { (場所) }\end{array}$ & $\begin{array}{l}\text { 腐 } \\
\text { 食 } \\
\text { 性 }\end{array}$ & $\begin{array}{l}\text { 温度 } \\
\left({ }^{\circ} \mathrm{C}\right)\end{array}$ & $\begin{array}{l}\text { 腐食速度 } \\
(\mathrm{mm} / \mathrm{y})\end{array}$ \\
\hline 原発復水管 & $\begin{array}{l}2004 \text { 年 } 8 \text { 月運転中の原子力発電所の夕ービン建屋（3 階建て）内 } \\
\text { で、配管が破裂して高温の蒸気が噴出し、 } 2 \text { 階で定期点検の準備作 } \\
\text { 業をしていた作業員 } 11 \text { 人のう、 } 4 \text { 人が死亡し、 } 2 \text { 人が重体、 } 5 \text { 人 } \\
\text { が重軽甥を負った。後日、重体の } 1 \text { 人も死亡した。運転中の原発の } \\
\text { 事故としては過去最悪の規模である。二次系配管なので、放射能污 } \\
\text { 染はなかった。配管破裂の原因は、エロージョン／コロージョンに } \\
\text { よる局部減肉である。 }\end{array}$ & 単相 & 0.48 & $\begin{array}{l}\text { オリフ } \\
\text { イス下 } \\
\text { 流部 }\end{array}$ & $\begin{array}{l}\text { 高 } \\
\text { 温 } \\
\text { 水 }\end{array}$ & 142 & 0.36 \\
\hline $\begin{array}{l}\text { 火力発電タービ } \\
\text { ン配管 }\end{array}$ & $\begin{array}{l}2004 \text { 年 } 8 \text { 月火力発電で、タービン建屋内の配管が破裂し、蒸気が } \\
\text { 漏洩する事故が起き、運転を停止した。人身事故無し }\end{array}$ & 単相 & 不明 & $\begin{array}{l}\text { バルブ } \\
\text { (弁)下 } \\
\text { 流 }\end{array}$ & $\begin{array}{l}\text { 高 } \\
\text { 温 } \\
\text { 水 } \\
\end{array}$ & 不明 & 0.93 \\
\hline $\begin{array}{l}\text { エタノールプラ } \\
\text { ント高圧エチレ } \\
\text { ン配管 }\end{array}$ & $\begin{array}{l}1997 \text { 年 } 5 \text { 月エタノール製造装置を定常運転中、エチレンを主とす } \\
\text { るリサイクルガスの高圧配管のT字部でエロージョン・コロージョ } \\
\text { ンが起きて減肉し、内圧に耐えられなくなってエチレンガスが漏 } \\
\text { れ、爆発、火災となった。水分を含んだ気液混相流が高速に流れて } \\
\text { いたため、著しく腐食が進んだ。 }\end{array}$ & 気液 & 14.5 & $\mathrm{~T}$ 字部 & $\begin{array}{l}\text { I } \\
\text { チ } \\
\text { レ } \\
\text { ン }\end{array}$ & 不明 & 不明 \\
\hline $\begin{array}{l}\text { メチルアミン製 } \\
\text { 造装置原料系配 } \\
\text { 管 }\end{array}$ & 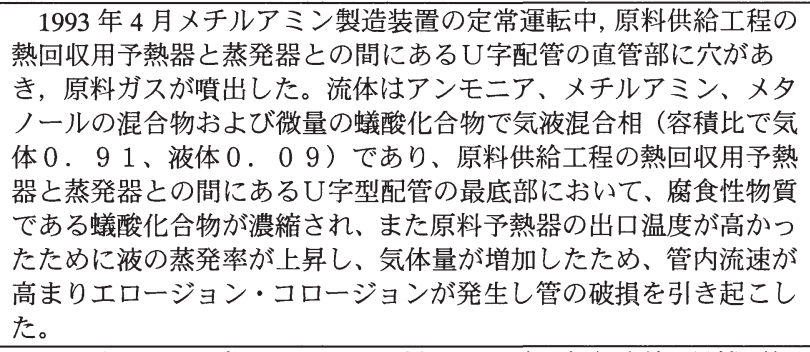 & 気液 & 12.5 & 直線部 & $\begin{array}{l}\text { 蟻 } \\
\text { 酸 }\end{array}$ & 高温 & 不明 \\
\hline $\begin{array}{l}\text { 原発給水系配管 } \\
\text { エルボ }\end{array}$ & 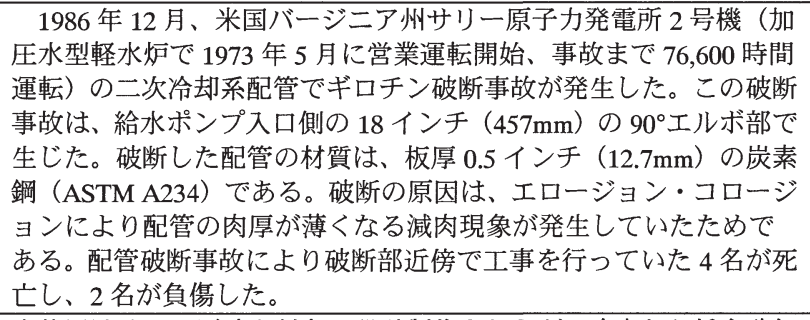 & 気液 & 不明 & エルボ & $\begin{array}{l}\text { ビ } \\
\text { ラ } \\
\text { ジ } \\
\text { ン } \\
\text { 添 } \\
\text { 加 }\end{array}$ & $\underset{330}{290}$ & 0.94 \\
\hline $\begin{array}{l}\text { 石油精製プラン } \\
\text { トトランスファ } \\
\text { ーライン炭素鋼 } \\
\text { 還流配管 }\end{array}$ & $\begin{array}{l}\text { 当装置はサワー原油を対象に設計製作されたが、途中から低全酸価 } \\
\text { のスウイート原油（ナイジェリア、アンゴラなどの西アフリカ産） } \\
\text { に切り替えられ、腐食損傷が発生した。加熱炉出口での } 330 〜 345^{\circ} \mathrm{C} \\
\text { の高い運転温度の影響が大きく、気化により高流速の二相流となり } \\
\text { ナフテン酸腐食した。 }\end{array}$ & 気液 & 15 & エルボ & $\begin{array}{l}\text { ナ } \\
\text { フ } \\
\text { テ } \\
\text { ン } \\
\text { 酸 }\end{array}$ & 230 & 不明 \\
\hline \multirow{2}{*}{$\begin{array}{l}\text { ナフサ搬送ポン } \\
\text { プインペラ }\end{array}$} & $\begin{array}{l}\text { スラリーを含有する高温ナフサを搬送する中型ポンプの炭素鋼製 } \\
\text { インペラが } 2 \text { ケ間でインペラ羽根がなくなるほど激しく減肉し } \\
\text { た。減肉速度は } 18 \mathrm{~mm} / \text { 年に相当する。 }\end{array}$ & 固液 & 不明 & $\begin{array}{l}\text { ポンプ } \\
\text { インペ } \\
\text { ラ }\end{array}$ & $\begin{array}{l}\text { ナ } \\
\text { フ } \\
\text { サ }\end{array}$ & 160 & 18 \\
\hline & $\begin{array}{l}\text { ポンプの炭素鋼製軸も同様に激しく減肉した。しかし、スラリーが } \\
\text { 強く接触しないポンプ構造なので、その減肉速度は } 2 \mathrm{~mm} / \text { 年以下で } \\
\text { ある。 }\end{array}$ & 単相 & 不明 & $\begin{array}{l}\text { ポンプ } \\
\text { 軸 }\end{array}$ & $\begin{array}{l}\text { ナ } \\
\text { フ } \\
\text { サ }\end{array}$ & 160 & 2 \\
\hline $\begin{array}{l}\text { 熱交換器出口配 } \\
\text { 管の水注入口下 } \\
\text { 流の曲管 }\end{array}$ & $\begin{array}{l}\text { ナフサ水添脱硫装置を運転中, コンバインド熱交換器出口配管の水 } \\
\text { 注入口下流のエルボが突然破損し,開口穴から気液混相流のプロセ } \\
\text { ス流体が噴出し火災となった。 }\end{array}$ & 気液 & 不明 & $\begin{array}{l}\text { 曲がり } \\
\text { 部 }\end{array}$ & $\begin{array}{l}\text { 硫 } \\
\text { 化 } \\
\text { 水 } \\
\text { 素 }\end{array}$ & 高温 & 不明 \\
\hline ポンプ出口配管 & $\begin{array}{l}\text { ポンプ吐出し側直下に存在する配管で、液流れ（旋回流）および含 } \\
\text { 有固形物によるエロージョンによって、円周方向にナイフで削った } \\
\text { ような規則的隇肉が発生した。 }\end{array}$ & 固液 & 不明 & 旋回流 & $\begin{array}{l}\text { 不 } \\
\text { 明 }\end{array}$ & 不明 & 17 \\
\hline $\begin{array}{l}\text { 熱炭酸力リ溶液 } \\
\text { による } \mathrm{CO} 2 \text { 吸 } \\
\text { 収液再生塔 }\end{array}$ & $\begin{array}{l}\text { アンモニアプラントにおいて、運転開始 } 2 \text { ケ月後に CO2 吸収液再 } \\
\text { 生塔中段部・液分散板取付け部（塔下部へのディストリビューター） } \\
\text { 付近の塔壁にクラック状開ロが発生し、プロセス液（K2CO3、 } \\
\left.\text { KHCO3、DEA、V2O5: } 0.8 \mathrm{~kg} / \mathrm{cm} 2 \mathrm{G} 、 123^{\circ} \mathrm{C}\right) \text { が漏出した。 } \\
\text { 塔外面からクラックにラバーを詰込み、金属バンドで締付けて漏れ } \\
\text { を止め、運転を継続しようと試みたが成功せず、漏出開始後 } 13 \text { 日 } \\
\text { 目にプラントを停止した。 }\end{array}$ & 単相 & 不明 & $\begin{array}{l}\text { 想定外 } \\
\text { の乱流 }\end{array}$ & $\begin{array}{l}\text { ア } \\
\text { ン } \\
モ \\
= \\
\text { ア }\end{array}$ & 123 & 不明 \\
\hline
\end{tabular}

テクニカルモデュールの作成に当たっては, エロージ ヨン・コロージョンによる実際の事故事例から損傷因子 を抽出し, 減肉量との因果関係をもとめ, 因子の係数化 をすれば，実用的な予測が可能になると考えた。
JST 失敗知識データベース ${ }^{2)}$ から「エロージョン」「コ ロージョン」「炭素鋼」をキーワードとして検索し，10 件の事例を得た。表 2 にそれらの損傷状況，腐食速度と 損傷因子を整理して示す。 
流体状態については検索結果 10 件のうち単相流によ る損傷事例は 2 件であり, 混相流によるものは 8 件（内, 気液が 5 件）であった。 また, 腐食速度が記載されてい るもので比較をすると, 固液はすべて $15 \mathrm{~mm} / \mathrm{y}$ 以上で あり, 単相流もしくは気液混相流のものは $1 \mathrm{~mm} / \mathrm{y}$ 程度 のものが多い.ナフサ搬送ポンプインペラの固形スラリ 一によるエロージョン・コロージョンの事故事例におい ては，スラリーが直接接触するインペラでは腐食速度が $18 \mathrm{~mm} / \mathrm{y}$ であるのに対し, スラリーが直接接触しない軸 材では $2 \mathrm{~mm} / \mathrm{y}$ であった。 以上より, 固液混相流では腐 食速度が一桁程度上昇することが分かる。

流速については流速が記載されていない，または流速 が記載されていても腐食速度が記載されておらず, 定量 的因果関係は明確ではないが, 事故事例には $10 \mathrm{~m} / \mathrm{s}$ 以 上の高い流速のケースが多く, 流速の影響が大きいこと が読み取れる。

乱流度合いについて, 配管系のエロージョン・コロー ジョンについては直線部での事例は事故 8 件中 1 件のみ であり，他はすべてエルボ部など乱流になりやすい領域 で起こっている.

流体の腐食性については, 多様の環境で事故が起きて いるが，何らかの腐食性を有した環境で事故が発生して いることは明白である。

温度については $150^{\circ} \mathrm{C}$ 付近で起こっている事例が多く, 温度が明記されている事例は $123,142,160,230^{\circ} \mathrm{C}$ であり， 常温より高温側での事故事例が多い.

\section{5. エロージョン・コロージョンの テクニカルモデュール作成}

エンジニアリング振興協会の「産業・社会資本構造物 の長寿命化に向けた高度メンテナンスシステムの開発」 プロジェクト 6) の研究の一環として開発したエロージョ ン・コロージョンの起こり易さを評価するテクニカルモ デュールを以下に紹介する。

\section{1 作 成 手順}

エロージョン・コロージョンは主に乱流域で発生し, 混相流によるものが著しい減肉を呈すること, 腐食速度 は一般に流速, 流体の種類と温度に依存することから， 流体状態, 流速, 形状 (乱流度合), 流体の腐食性, 温. 度の 5 つをエロージョン・コロージョンの影響因子とし て挙げた。これら影響因子に係数付けし, 係数を累積し た值でエロージョン・コロージョンの起こり易さを表現 するものとした. 係数付けおよび累積方法は, 専門家に よる委員会を設置し，4. で述べた事例における因果関係 をもとに専門家の知識, 経験から, 影響因子の影響度合 いを検討し決定した。

流体状態は, 単相を基準（係数 1）とし, 気体-液体の 混相について係数 3 , 固体が混ざった場合, エロージョ ンの効果が著しくなり減肉が急加速すると判断し, 液 体-固体の混相では係数を 20 とした.

流速は, 通常 $10 \mathrm{~m} / \mathrm{s}$ 未満で設計されていることが多 く, 係数を 1 とし, $10 \mathrm{~m} / \mathrm{s}$ 以上では急激な加速があると 判断し，係数を 5 とした。

乱流の度合は, 構造物（配管など）の形状によって決
まると判断した，通常流れの直線部（直管など）ではエ ロージョン・コロージョンの発生は見られないことか ら, 流れの直線部を係数 1 とし, 内径の変化する曲がり 部, オリフィスなど流れが乱れる部位について係数 10 とした。

流体の腐食性については, 特に腐食性が問題とならな い物質で腐食抑制対策をしてない場合を係数 1 , 防食対 策をしている場合を係数 0.5 , また特に腐食性が高い場 合に係数を 4 とした。

材料温度については, 基本的に腐食, エロージョンと も温度が高い側で進行が早いと判断し, $100^{\circ} \mathrm{C}$ 未満を係 数 1 とし, 高温側で係数を高く設定した.

\section{2 利用手順}

このテクニカルモデュールの適応範囲は，次のとおり とする。

対象材料：炭素鋼

温度： $300^{\circ} \mathrm{C}$ 未満（ドライ環境は除く）

環境：pH は 4 10 の範囲（pH 4 未満では酸による 単純腐食となり, pH 10 以上では腐食が抑制 されるので除外する)

以下の順に使用条件を入力し, 係数を求め, 累積係数 と使用期間によって余寿命および破損の起こりやすさレ ベルを決定する。

\subsection{1 因子と係数}

(1) 流体状態

表 3 流体状態と係数 $\mathrm{C}_{1}$

\begin{tabular}{|c|c|c|}
\hline \multicolumn{2}{|c|}{ 流体状態 } & 係数 $\mathrm{C}_{1}$ \\
\hline \multicolumn{2}{|l|}{ 単相 } & 1 \\
\hline \multirow{2}{*}{ 混相 } & 気体－液体 & 3 \\
\hline & 液体－固体 & 20 \\
\hline
\end{tabular}

(2) 流体速度

表 4 流体速度と係数 $\mathrm{C}_{2}$

\begin{tabular}{c|c}
\hline 流体速度 & 係数 $\mathrm{C}_{2}$ \\
\hline $10 \mathrm{~m} / \mathrm{s}$ 未満 & 1 \\
\hline $10 \mathrm{~m} / \mathrm{s}$ 以上 & 5 \\
\hline
\end{tabular}

(3) 乱流度合（形状）

表 5 乱流度合 (形状) と係数 $\mathrm{C}_{3}$

\begin{tabular}{c|c}
\hline 乱流度合 (形状) & 係数 $\mathrm{C}_{3}$ \\
\hline 配管の直線部など & 1 \\
配管曲がり部 (エルボなど), バルブの下流部, & 10 \\
オリフィス後流, 管径の減少部, 旋回流部など & 10 \\
\hline
\end{tabular}

(4) 流体の腐食性

表 6 流体の腐食性と係数 $\mathrm{C}_{4}$

\begin{tabular}{l|c}
\hline \multicolumn{1}{c|}{ 流体の腐食性 } & 係数 $\mathrm{C}_{4}$ \\
\hline 腐食抑制対策あり(インヒビターなど) & 0.5 \\
\hdashline 腐食抑制対策なし & 1 \\
\hdashline 特に腐食性が高い & 4 \\
\hline
\end{tabular}


(5) 材料の温度

表 7 材料の温度と係数 $\mathrm{C}_{5}$

\begin{tabular}{c|c}
\hline 材料の温度 & 係数 $\mathrm{C}_{5}$ \\
\hline $100^{\circ} \mathrm{C}$ 未満 & 1 \\
\hline $100^{\circ} \mathrm{C}$ 上, $200^{\circ} \mathrm{C}$ 未満 & 2 \\
\hline $200^{\circ} \mathrm{C}$ 以上, $300^{\circ} \mathrm{C}$ 未満 & 2.5 \\
\hline
\end{tabular}

\section{2 .2 累積係数と減肉速度目安}

上記各係数の積（式 1）を累積係数として, 表 8 に累 積係数と減肉速度の目安を示す。

累積係数 $=\mathrm{C}_{1} \times \mathrm{C}_{2} \times \mathrm{C}_{3} \times \mathrm{C}_{4} \times \mathrm{C}_{5}$

表 8 累積係数と減肉速度目安（破損感受性レベル）

\begin{tabular}{c|c}
\hline \multicolumn{1}{c|}{ 累積係数 } & 減肉速度目安 \\
\hline 5 未満 & $0.05 \mathrm{~mm} /$ 年 \\
\hline 5 以上, 200 未満 & $0.25 \mathrm{~mm} /$ 年 \\
\hline 200 以上, 400 未満 & $1.0 \mathrm{~mm} /$ 年 \\
\hline 400 以上 & $3.0 \mathrm{~mm} /$ 年 \\
\hline
\end{tabular}

\section{2 .3 余寿命評価}

エロージョン・コロージョンの余寿命評価を行う場合 は，式(2)および(3)により計算する.

全寿命 $($ 年 $)=$ 余肉 $(\mathrm{mm}) /$ 減肉速度 $(\mathrm{mm} /$ 年 $)$

ここで, 余肉 : 実肉厚 $(\mathrm{mm})$ - 必要最小肉厚 $(\mathrm{mm})$, 減 肉速度 $(\mathrm{mm} /$ 年 $):$ 表 8 の減肉速度目安.

余寿命 $($ 年 $)=$ 全寿命 $($ 年 $)-$ 使用期間 $($ 年 $)$

注）式(2) の実肉厚は通常建設時の肉厚計測值を使用 するが，運転中に対象部位の肉厚を正確に計測している 場合，その值を用い，式(3) の使用期間は，検査実施後 の期間を使用する.

以上のテクニカルモデュールのフローを図 4 に示す.

\subsection{4 リスク評価への適用}

半定量的リスク評価における「破損の起こりやすさ」 のレベルは, 5.2.3で求めた余寿命から表 9 によって求 めることができる（このレベル分けは目安であり，使用 者の判断で変更できる).

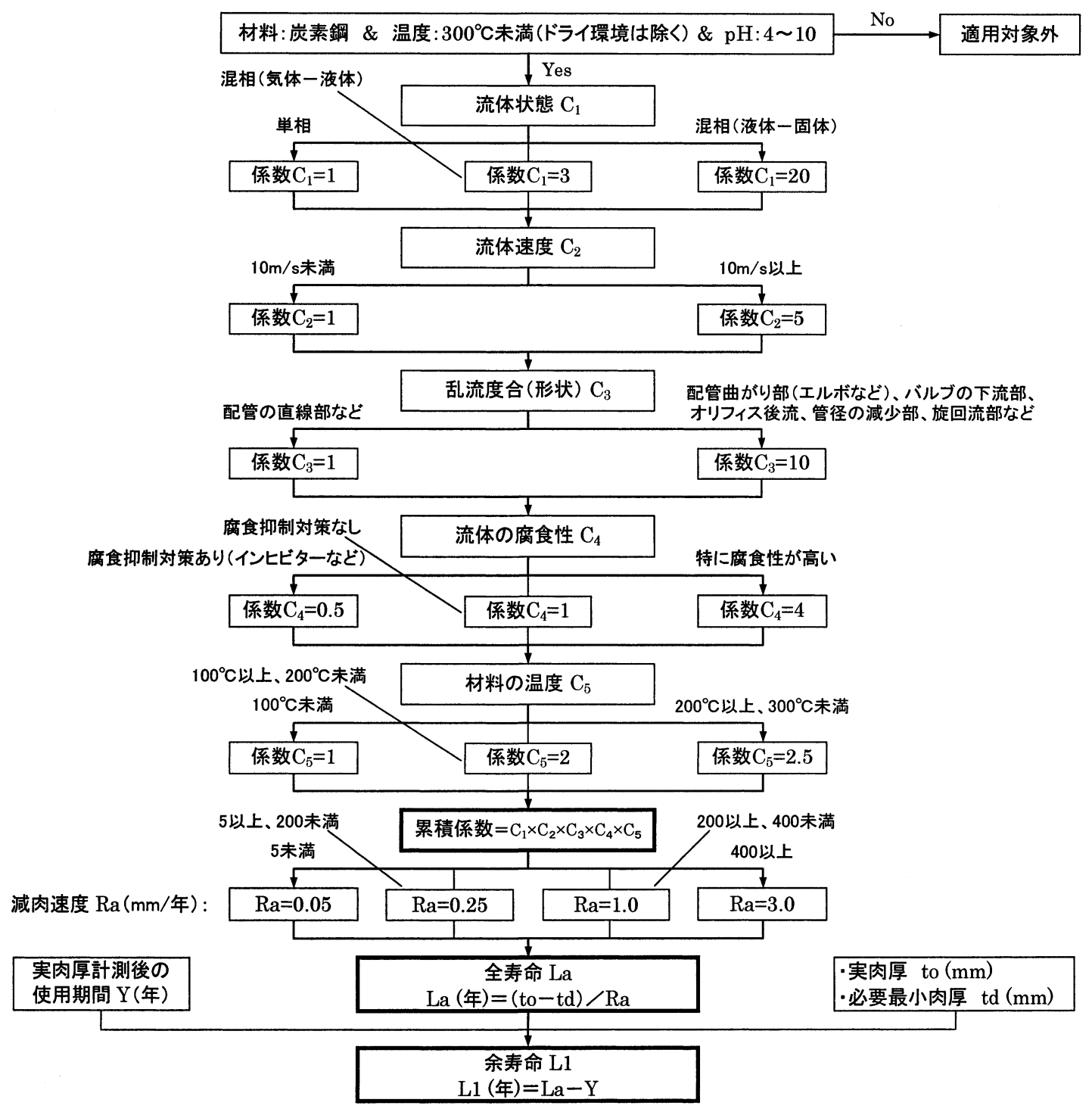

図 4 エロージョン・コロージョンのテクニカルモデュールのフロー 
表 9 余寿命と破損の起こりやすさレベル

\begin{tabular}{l|c}
\hline \multicolumn{1}{c|}{ 余寿命 } & 破損の起こり易さレベル \\
\hline 15 年以上 & 1 \\
\hline 8 年以上, 15 年未満 & 2 \\
\hdashline 2 年以上, 8 年未満 & 3 \\
\hline 2 年未満 & 4 \\
\hline
\end{tabular}

\section{6.お おりに}

本報告では，(財)エンジニアリング振興協会「産業・ 社会資本構造物の長寿命化に向けた高度メンテナンスシ ステムの開発」プロジェクトの開発成果の一つであるエ ロージョン・コロージョンの起こり易さ算定のツールで あるテクニカルモデュールを紹介した. テクニカルモデ ユールは RBI/RBM における破損の起こり易さ算定の手 段であるとともに，通常の寿命評価などに有効に活用で きる，蓄積された損傷データ，専門家および経験者の知 識と経験を含有したもので，技術伝承の道具ともいえる. しかし，あくまでも損傷の程度を相対的に比較する目安 として使用すべきもので, 減肉速度などの定量的值には 期待を持つべきではないと考える.

また，本テクニカルモデュールを用いて表 2 に示され ている事例を当てはめて見ると, 実際の減肉量が予測值 を上回るものがあり，係数付けについて再検討が必要な ことを示唆している. 現状では, 事例件数および影響因 子と腐食速度の因果関係についての情報量が不足してい る。本テクニカルモデュールの係数の組み合わせは 108 通りあり，正確に検証するには多量の情報量が必要とな る．実際のプラントでの損傷評価に適用して改良を加え ることで，信頼性を向上させることができるので，メン テナンス関係者による適用，検証，改善を期待している.

また，他の損傷機構についても同様のテクニカルモデ ユールの開発が進むことが望まれる。

\section{参 考 文 献}

1）（社）日本高圧力技術協会材料分野情報収集委員会, 失敗 知識データベース (材料分野) 報告書, 平成 18 年 2 月 $\mathrm{p}$ I-1-4.

2) JST 失敗知識データベース，科学技術分野の事故や失敗 の知識と教訓, URL : http://shippai.jst.go.jp/fkd/Search.

3）小林英男，「高圧ガス製造設備の保安検査方法の制度改 正」, HPI セミナー第 6 回圧力容器関連規格の国内外動 向，(社) 日本高圧力技術協会，平成 17 年 1 月 27 日.

4）神門正雄，「高圧ガス保安協会における規格策定プロセ スの抜本的見直しについて」, HPI セミナー第 6 回圧力 容器関連規格の国内外動向, (社) 日本高圧力技術協会, 平成 17 年 1 月 27 日.
5）富士彰夫ほか; リスクベースメンテナンス (RBM), 配 管技術，46[1] 71 (2004).

6) 平成 18 年度戦略的技術開発（構造物長寿命化高度メン テナンス技術開発）報告書，（財)エンジニアリング振興 協会 (2007).

7) American Petroleum Institute, "Risk-Based Inspection", API Recommended Practice 580, (2002.5).

8) American Petroleum Institute, "Risk-Based Inspection Base Resource Document”, API Publication 581, (2000.5).

9) The American Society of Mechanical Engineers (ASME), "Risk-Based Inspection-Development of Guidelines", vol.1 General Document, CRTD-Vol.20-1, (1991).

10) ASME, "Risk-Based Inspection-Development of Guidelines”, vol.3 Fossil Fuel-Fired Electric Power Generating Station Application, CRTD-Vol.20-3, (1994) .

11) EPRI, "Risk-Informed In-service Inspection Evaluation Procedure”, EPRI TR-106706, (June 1996).

12) ASME, "Risk Informed Requirements for Class $1,2 \& 3$ Piping, Method B", N-578, (Sep.1997).

13) ASME, "Risk Informed Requirements for Class 1, $2 \& 3$ Piping, Method A", N-577, (Sep.1997).

14）「高稼動率技術開発 定期点検 - 定期検査の高度化に関す る検討（フェーズ II）(OPI)」, 発電技検レビュー, No.24, p.103 (1998).

15）柴崎敏和，HPI の RBM 専門研究委員会により提案予定 の RBM ガイドの紹介, HPI セミナー第 5 回「リスクベ ースメンテナンスの基礎と応用」平成 18 年度，日本高 圧力技術協会, p.35.

16）石丸 裕, HPI の RBM 専門研究委員会により提案予定の $\mathrm{RBM}$ ハンドブックの紹介, HPI セミナー第 5 回「リス クベースメンテナンスの基礎と応用」平成 18 年度, 日 本高圧力技術協会, p. 55 .

17）「機械システム等のメンテナンス最適化のための RBM 手法の開発に関するフィージビリティースタディ」報告 書, (財) 機械システム振興協会, 委託先 (財) エンジニ アリング振興協会, 平成 17 年 3 月.

18) S. Kihara, A. Fuji, T. Okatsuka, I. Kajigaya, M. Yatomi, H. Eguchi and C. Fukuoka, Therm. Power, 52 [4] 27 (2001).

19) A. Fuji, et al., J. Jpn. Inst. Met., 66 [12] 1192 (2002).

20) S. Kihara, et al., J. Jpn. Soc. Mech, Eng., 106 [1019] 873 (2003).

21) H. Anzai et al., Advanced Risk Assessment of LNG Storage Tanks Based on Risk-Based Maintenance Planning, Int. Cof. of LNG (LNG-14), Doha, (2004.).

22）富士彰夫, リスクベースメンテナンスのクレーン設備へ の適用，日本機械学会講習会 No.01-89, p.63-70 (2002).

23) J.Takahashi, T.Node, N.Hatta, M. Torigoe, H.Eguchi, A.Fuji, S.Kihara, and M.Shipley, Application of Risk-Based Maintenance with Life and Financial Assessment on Cement Plants, ACSIM2002, Systems Integrity and Maintenance, Cairnsp.323 (2002).

24） K. Fujiyama, et al., J.Jpn.Inst.Met., 66 [12］1199 (2002).

25）木原重光，富士彰夫，「RBI/RBM 入門」，日本プラント メンテナンス協会（2002）

26） M. G. Stewart and R. E. Melchers（酒井信介 監訳），「技術 分野におけるリスクアセスメント」，森北出版（株） (2003).

27) H. H. Uhlig, "Uhlig's Corrosion Handbook".

28) Welding Research Council, "Damage mechanism affecting fixed equipment in pulp and paper industry", WRC489, (2004).

29) Corrosion Handbook (Jpn.) (1998).

(2007 年 6 月 25 日受理)

リスクを基準とするメンテナンス（RBI/RBM）において破損の起こり易さを求める手法として, 損傷機 構別のテクニカルモジュールが使われている。テクニカルモジュールは，対象となる部位の使用条件を入 力すると破損確率, 発生感受性, 余寿命などが算出できる手順を示したものである。本解説では, エロー ジョン・コロージョンに対するテクニカルモジュールの作成方法, 使用手順および問題点などを述べる.

キーワードエロージョン・コロージョン，リスクベースメンテナンス， RBM，テクニカルモジュ ール，減肉速度，余寿命 